Available online at : http://journal.unj.ac.id/unj/index.php/gjik

Gladi : Jurnal Ilmu Keolahragaan 12 (03) Special Issue 2021, 34-39 Permalink/DOI: https://doi.org/10.21009/GJIK.123.05

\title{
KNOWLEDGE AND ATTITUDES TOWARD DRUG HAZARDS IN JUNIOR HIGH SCHOOL STUDENTS
}

\author{
Kecuk Tri Prasetya ${ }^{1}$, Junaidi ${ }^{1}$, Ika Novitaria Marani ${ }^{1}$ \\ ${ }^{1}$ Physical Education, Univeristas Negeri Jakarta, Jl. Rawamangun Muka, RT.11/RW.14, Rawamangun, \\ Pulo Gadung, Kota Jakarta Timur, Daerah Khusus Ibukota Jakarta 13220 \\ Correspondiing author. Email : KecukTriPrasetya_9903820008@mhs.unj.ac.id
}

\begin{abstract}
Abstrak This study aims to determine the effect of drug knowledge and attitudes towards the dangers of drugs in elementary school students. This study used a descriptive research design using a cross-sectional approach. The research samples were students Depok Junior high school 1, West Java. The sampling technique in this study was taken by using the probability sampling method, namely the Simple Random Sampling method. The data collection instrument in this study was to use a questionnaire in the form of a number of written questions. Result. Of the 74 respondents, the results of the knowledge level test showed that 67 students of Depok Junior high school 1, West Java had a good level of knowledge of drugs (90.5\%). 74 people (100\%) had a positive attitude towards drugs and the results of the behavior test showed that the number of elementary school students with good behavior towards drugs was 63 people $(85.1 \%)$. Conclusion. Students Depok Junior high school 1, West Java has a good level of knowledge, attitude, and behavior towards drugs
\end{abstract}

Keywords: knowledge, attitudes, Drugs 


\section{INTRODUCTION}

Indonesia is in a serious condition for drugs, it is estimated that the number of drug abusers is 3.8 million to 4.1 million people or around $2.10 \%$ to $2.25 \%$ of the total population of Indonesia who are at risk of drug exposure in 2014, in 1 year 18,000 people died the result of this drug is that it is not a small number, it is already an emergency condition(Pusat penelitian data dan informasi BNN, 2017), (Afiatin, 2004)

The results of a survey by the National Narcotics Agency in 2017, the proportion of drug abuse based on dependency level: non-injection addicts $14.49 \% \quad(489,197$ people $)$ injection addicts $1.73 \%$ (58,498 people), regularly use $27.25 \%$ (920,100 people), try $59.53 \%$ $(1,908,319$ people) there were $3,376,115$ drug abusers in the 10-59year age group. The largest proportion of drug abuse based on the group of workers is 59\% $(1,991,909$ people $)$, the student group is $24 \%(810,267$ people $)$, the general population group is $17 \%$ (573,939 people) of a total of 3,376,115 people (Pusat penelitian data dan informasi BNN, 2017), meaning that the student group ranks second as vulnerable to drug abuse after the worker group, among students, especially those in elementary school, drug consumption usually begins with smoking (Komasari \& Helmi, 2011). This happens usually because of offers, persuasion, or pressure.

The National Narcotics Agency records data on citizens who are users and Drugs affected in West Java Province as one of the major provinces in Indonesia with 18 districts and 9 cities with a total population of 46,709,569 residents (BNN PUSLIDATIN, 2020). The results of the 2018 BNN and LIPI research stated that $5.5 \%$ or the equivalent of 1.1 million people have used drugs in the city of Bandung. This figure is not a small number and cannot be considered as a normal problem. Moreover, the highest contributor to the prevalence rate of drug abuse in West Java is the student group, West Java has several cities that have status as a buffer for the capital and are the distribution of drugs, such as Bogor, Depok, Bekasi, and Sukabumi. The four cities are currently categorized as drugprone areas. Various methods are created and developed by drug syndicates to maintain market or consumer sustainability. One of them is the "market regeneration" method. This method is implemented by feeding early childhood with drugs that are "disguised" in food or candy. The goal is that from an early age, he is unconsciously active as a drug user, so that his body will experience tolerance for drugs and mentally will experience addiction or dependence. So that at the age of adolescence or adulthood, the person concerned will become an active user or drug addict and become a potential market share for drug distribution.

Here the role of the teacher is needed to guide students in solving problems faced by directing students to more positive behavior, developing student abilities, and providing learning motivation to students.

Efforts to prevent drug abuse include the role in school educational institutions, namely continuously and continuously providing knowledge about the dangers of drugs and forming student attitudes so as not to fall into drug abuse. and easily influenced by the environment and peers. Among students, especially those in elementary school, junior high school and high school, drug consumption usually begins with smoking. This happens usually because of offers, persuasion, or pressure from certain parties (Fidrayani \& Utami, 2018)

Based on the introduction described above, the formulation of the problems that can be concluded is: What 
is the level of knowledge, attitudes and behavior of students towards drugs?

\section{METHODS}

This study used a descriptive research design using a cross-sectional approach to determine the level of knowledge, attitudes and behavior of Depok Junior high school 1, West Java students towards drugs.

\section{Participants}

This research was conducted at Depok Junior high school 1, West Java Jl. Pemuda No.53 Pancoranmas, Depok City Prov. West Java. The population in this study were grade 7 students, grade 8 students and grade 9 Depok Junior high school 1, West Java students.

The sampling technique in this study was taken with a probability sampling method, namely the Simple Random Sampling method (Acharya et al., 2013). With random sampling, all elements in the population will have the same chance to be taken as a sample to represent the population and the sample will be taken based on randomization of student serial numbers.

\section{Instrument}

The data collection instrument in this study was to use a questionnaire in the form of a number of written questions. The making of this questionnaire refers to a review of the theory that the researcher has presented on his research. The data collection instrument in this study used a questionnaire consisting of 3rd questionnaires, namely a knowledge level questionnaire, an attitude questionnaire, and a behavior questionnaire. Before the questionnaire is introduced to the respondent, the instrument must be tested with the intention of getting a good instrument, this instrument must meet the important data requirements, namely validity and reliability

\section{RESULTS}

Data processing is carried out in the following steps: (1) editing, is carried out to check the accuracy and completeness of the data; (2) coding, data that has been collected is corrected, then coded by the researcher manually before being processed by computer; (3) entry, the data is entered into a computer program; (4) data cleaning, checking all data that has been entered into a computer in order to avoid errors in data entry; (5) saving, data storage for ready analysis; and (6) data analysis. The data is then processed using statistical software and presented in tabular form with the aim of research, namely to determine the level of knowledge, attitudes and behavior of students at Depok Junior high school 1, West Java towards drugs.

The subjects of this study were students at Depok Junior high school 1, West Java. From a total of 851 students at the Depok Junior high school 1, West Java, 74 respondents became the research respondents. The research respondents consisted of 35 male students (47.3\%) and 39 female students $(52.7 \%)$ (Table 1$)$

Table 1. Descriptive Analysis Result

\begin{tabular}{lcc}
\hline Gender & $\begin{array}{c}\text { Frequency } \\
\text { (people) }\end{array}$ & Percentage (\%) \\
\hline Men & 35 & $47.3 \%$ \\
\hline Women & 39 & $52.7 \%$ \\
\hline Total & 74 & $100 \%$ \\
\hline
\end{tabular}

Research respondents were evenly distributed at each grade level (Table 4.2), with 25 students in grade 7 Junior High School 1 Depok (33.8\%), Grade 8 Junior High School 1 Depok as many as 24 people $(32.4 \%)$ and grade 9 Junior High 
School 1 Depok, as many as 25 people $(33.8 \%)$.

Table 2. Frequency distribution of respondent characteristics by class

\begin{tabular}{ccc}
\hline Grade & Frequency (people) & Percentage $(\%)$ \\
\hline Grade 7 & 25 & $33.8 \%$ \\
\hline Grade 8 & 24 & $32.4 \%$ \\
\hline Grade 9 & 25 & $33.8 \%$ \\
\hline total & 74 & $100 \%$ \\
\hline
\end{tabular}

The results of the test on the level of knowledge of the Depok Junior high school 1, West Java students which were carried out using a questionnaire can be seen in table 2 .

Table 3. Test results on the level of respondent's knowledge of drugs

\begin{tabular}{cccc}
\hline $\begin{array}{c}\text { Knowledge } \\
\text { Level }\end{array}$ & Score & $\begin{array}{c}\text { Frequency } \\
\text { (people) }\end{array}$ & $\begin{array}{c}\text { Percentage } \\
(\%)\end{array}$ \\
\hline Good & $14-20$ & 67 & $90.5 \%$ \\
\hline Moderate & $7-13$ & 7 & $9.5 \%$ \\
\hline Less & $0-6$ & 0 & 0 \\
\hline Total & & 74 & $100 \%$ \\
\hline
\end{tabular}

Table 4. Test results on the level of respondent's knowledge of drugs based on gender

\begin{tabular}{cccccc}
\hline \multirow{2}{*}{ Gender } & \multicolumn{4}{c}{ Knowledge Level } & \multirow{2}{*}{ Total } \\
\cline { 2 - 5 } & \multicolumn{2}{c}{ Good } & \multicolumn{2}{c}{ Moderate } & \\
\cline { 2 - 5 } & $\mathrm{F}$ & $\%$ & $\mathrm{f}$ & $\%$ & \\
\hline Men & 32 & 47.8 & 3 & 42.9 & 35 \\
\hline Women & 35 & 52.2 & 4 & 57.1 & 39 \\
\hline Total & 67 & 100 & & 100 & 74 \\
\hline
\end{tabular}

Table 5. The results of the test of the respondent's level of knowledge of drugs by grade

\begin{tabular}{|c|c|c|c|c|c|}
\hline \multirow[t]{3}{*}{ Grade } & \multicolumn{4}{|c|}{ Knowledge Level } & \multirow{3}{*}{ Total } \\
\hline & \multicolumn{2}{|c|}{ Good } & \multicolumn{2}{|c|}{ Moderate } & \\
\hline & $\mathrm{F}$ & $\%$ & $\mathrm{f}$ & $\%$ & \\
\hline Grade 7 & 23 & 34.3 & 2 & 28.6 & 25 \\
\hline Grade 8 & 24 & 35.8 & 0 & 0 & 24 \\
\hline Grade 9 & 20 & 29.9 & 5 & 71.4 & 25 \\
\hline Total & 67 & 100 & 7 & 100 & 100 \\
\hline
\end{tabular}

Table 4. shows that out of 67 students with a good level of knowledge, the largest proportion is $24(35.8 \%)$ were grade 8 students.

From the results of the knowledge level test above, it was found that the number of junior high school students 1 Depok with a good level of knowledge of drugs was as much as $90.5 \%$. The level of knowledge based on gender is obtained by the majority of students who have a good level of knowledge are women, the level of knowledge based on the class obtained a good level of knowledge, the majority are students of grade 8 Junior High School 1 Depok.

These results indicate that the majority of junior high school 1 Depok students have a good level of knowledge about drugs. This happens because students get strong information and education about drugs. The results of the attitude test of junior high school 1 Depok students which were carried out using a questionnaire can be seen in table 6 .

Table 6. Test results of respondents attitudes towards drugs.

\begin{tabular}{cccc}
\hline Attitudes & Score & $\begin{array}{c}\text { Frequency } \\
\text { (people) }\end{array}$ & $\begin{array}{c}\text { Percentage } \\
(\%)\end{array}$ \\
\hline Positive & $\geq$ & 74 & 100 \\
\hline Negative & $<$ & 0 & 0 \\
\hline Total & & 74 & 100 \\
\hline
\end{tabular}

From the results of the attitude test above, it was found that the number of junior high school students 1 Depok with positive attitudes towards drugs was as much as $100 \%$. Because the knowledge about drugs that has been obtained in school, they tend to have a good attitude towards drugs. The results of this study indicate that the majority of junior high school students 1 Depok have a positive attitude towards drugs.

This study indicate that the majority of junior high school students 1 Depok have a positive attitude towards drugs. Based on one of the studies conducted by Asti, Y. (2014), this can 
happen because students have good knowledge (internal factors) and environmental, social and cultural (external factors). Internal factors that cause adolescence to be included in the group of drug abusers are the desire to know / try, want to be appreciated, and depression as well as the lack of religious values. External factors causing drug abuse in adolescence are peer influence, lack of parental attention, broken home (a condition where the family experiences a split or a gap in the household), and mass media (Asti, 2014).

\section{Discussion}

Some things that can be recommended from the results of this study are:

1. For research subjects.

Students must be able to know matters relating to the types, effects and spread of drugs in order to avoid drug abuse.

2. For schools

Providing counseling is needed to provide insight to junior high school students about drugs and how to make students free from drug abuse considering that adolescence is an age that is vulnerable to deviations towards drugs.

\section{CONCLUSIONS}

Based on the research results from the data obtained, the conclusions that can be drawn in this study are as follows:

1. Overall, it was found that the majority of junior high school students 1 Depok have a good level of knowledge (90.5\%), a positive attitude (100\%) and good behavior $(85.1 \%)$.

2. The level of knowledge that is categorized as good, is dominated by students of grade 8 SMP as much as $35.8 \%$ (24 people).

3. All students of Junior High School 1 Depok have a positive attitude.

\section{REFERENCES}

Acharya, A. S., Prakash, A., Saxena, P., \& Nigam, A. (2013). Sampling: why and how of it? Indian Journal of Medical Specialities, 4(2). https://doi.org/10.7713/ijms.2013.00 32

Afiatin, T. (2004). Pengaruh Program Kelompok "Aji” Dalam Peningkatan Harga Diri, Asertivitas, Dan Pengetahuan Mengenai Napza Untuk Prevensi Penyalahgunaan Napza Pada Remaja. Jurnal Psikologi, 1, 28-54.

file:///C:/Users/USER/Downloads/36 -71-2-PB.pdf

Asti, Y. (2014). Hubungan Pengetahuan Dan Sikap Terhadap Perilaku Penyalahgunaan Narkoba Pada Siswa / I Smp Negeri 4 Kecamatan Pontianak Timur Kotamadya Pontianak Tahun 2013 Yeli Asti Nim I11108047 Program Studi Pendidikan Dokter.

BNN, P. (2020). Permasalahan Narkoba Di Indonesia 2019.

Fidrayani, \& Utami, D. (2018). Program Sekolah dalam Upaya Pencegahan Napza. 14(1), 1-26.

Komasari, D., \& Helmi, A. F. (2011). Faktor Faktor Penyebab Merokok Pada Remaja. Jurnal Psikologi, 27(1), 37-47.

Pusat penelitian data dan informasi, B. (2017). Survei Nasional Konsumsi Narkoba di 34 Provinsi Tahun 2017. Jurnal Data Puslitdatin 2017, II(1), 83-88.

https://rumahcemara.or.id/book/surve i-nasional-penyalahgunaan-narkobadi-34-provinsi-tahun-2017/ 